\title{
Brachyiulus jawlowskii Lohmander, 1928, a millipede species new to the fauna of Poland (Myriapoda: Diplopoda)
}

\author{
Piotr JASTRZĘBSKI \\ Siedlce University of Natural Sciences and Humanities, Department of Zoology, Prusa 12, 08-110 Siedlce, Poland; \\ e-mail:pjast@uph.edu.pl.
}

\begin{abstract}
The widespread East European millipede Brachyiulus jawłowskit is being reported from Poland for the first time, currently representing the northwesternmost record.
\end{abstract}

Key words: Myriapoda, millipede, Brachyiulus jawłowskit, new record, Poland

\section{INTRODUCTION}

The basically Euro-Mediterranean genus Brachyiulus Berlese, 1884 is known to encompass eight valid species (Enghoff \& Kime 2004). A few of them are quite local in distribution, being confined to several rather small areas in the Apennines or Balkans, but the others are more widespread. Thus, B. bagnalli (Brolemann, 1924) is common in Central and southern Europe while B. pusillus (Leach, 1814) occurs nearly throughout Western Europe and Scandinavia, having also been introduced to many places across the world (Blower 1985). These two congeners have been the only Brachyiulus species hitherto known from Poland (Stojalowska \& Starega 1974). One more, B. lusitanus Verhoeff, 1898, is pan-Mediterranean, reaching the Near East, the Caucasus and even Central Asia in the east (Golovatch 1979a, 1979b).

B. jawlowskii is widely distributed across Eastern Europe, having been reported from Romania, Moldova, Ukraine and Russia (Lokšina 1969, Chornyi \& Golovatch 1993, Prisnyi 2002, Enghoff \& Kime 2004). Golovatch (1984) and Chornyi \& Golovatch (1993) consider $B$. jawlowskii as one of the diplopods subendemic to the forested steppe belt of the Eastern European, or Russian, Plain, but actually ranging from the taiga (= boreal coniferous forest) zone in the north to the semi-desert belt in the south. Based on abundance data from large-scale quadrat sampling across the Plain, the ecological optimum for B. jawlowskii seems to lie within the steppe belt east of the Dnepr, in the lower Don Basin (Wytwer et al. 2009). This species mostly lives in litter in various habitats, yet never being numerous there.

B. jawlowskii has been found in the valley of Bug River (the Landscape Park "Podlaski Przelom Bugu") near the villages of Mogielnica and Mierzwice. The study areas are situated on river mud sediments overgrown by inundated fresh meadows (Poa pratensis-Festuca rubra) mowed twice during the vegetation season. Only 3 males and 2 females of B. jawlowskii have been collected there.

\section{MATERIAL EXAMINED}

The Landscape Park "Podlaski Przełom Bugu": Mierzwice (N 52 $2^{\circ} 19^{\prime}$ E 23 ${ }^{\circ}$ '): 1 male, inundated fresh meadow, 31 March 2008, leg. I. Hajdamowicz; Mogielnica (N 52 $24^{\prime}$ E $22^{\circ}$ 34'): 1 male, 2 females, inundated fresh meadow, 14 April 2008, leg. I. Hajdamowicz;

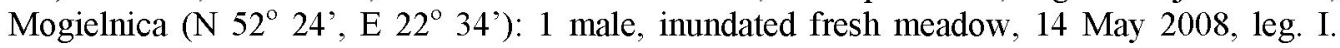
Hajdamowicz. 

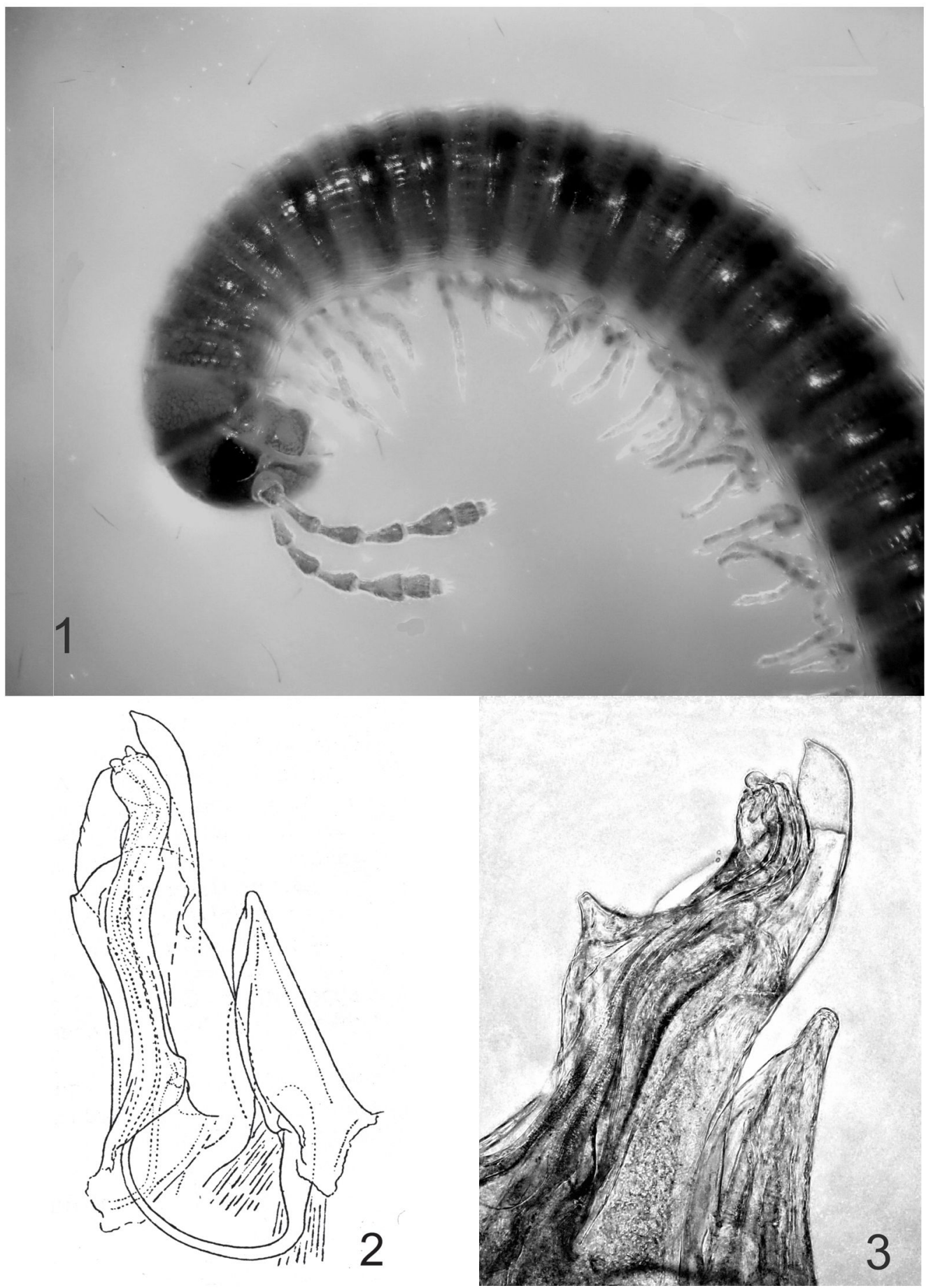

Figs 1-3. Male of Brachyiulus jawlowskii Lohmander, 1928: 1 - Anterior body part, lateral view; 2 - Sketch of the right gonopod (mesial view) by Lohmander (1928); 3 - Photo of the right gonopod of a male from Mierzwice, leg. P. Jastrzębski 


\section{COMMENTS}

A brief description of a male is given below to document the discovery. The present record not only adds $B$. jawlowskii to the Polish list, but also provides the northwesternmost range limit of the species

Measurements: body length (specimen broken) $12.08 \mathrm{~mm}$, width $0.78 \mathrm{~mm}$. Head and trunk shining, brownish. Collum a little lighter than trunk (Fig. 1). Two longitudinal, dorsal, paramedian, narrow, light stripes separated by a narrow, dark, axial line. Metazonital striation quite clear, rather sparse. Epiproct short, only slightly projecting behind pale yellow paraprocts, the latter bearing a few setae. Legs light brown. First pair of legs in male modified into small hooks. Gonopods as in Figs $2 \& 3$.

\section{ACKNOWLEDGEMENTS}

The present research was supported financially by the Polish Ministry for Science (grant nr N304 113 32/4128). I would like to thank the authorities of the Landscape Park "Podlaski Przelom Bugu" and my colleagues who share with me the grant. Sergei Golovatch (Moscow, Russia) kindly helped to improve of the manuscript.

\section{REFERENCES}

BLower J. G. 1985. Millipedes. Synopsis of the British Fauna (New Series) No. 35. E.J. Brill/Dr W. Backhuys, London, $242 \mathrm{pp}$.

CHORny N. G. \& Golovatch S. I. 1993. Millipedes (Diplopoda) of the plain territories of the Ukraine. Kiev, 54 pp. [In Russian, English summary]

ENGHOFF H. \& Kime R. D. 2004. Fauna Europaea: Brachyiulus. In ENGHOFF H. (ed.), Fauna Europaea: Diplopoda, Julidae. Fauna Europaea version 1.1, http://www.faunaeur.org

GoLovatch S. I. 1979a. The composition and zoogeographical connections of the Diplopoda of the Middle Asian fauna. Report 1. Zoologicheskiy Zhurnal 58 (7): 987-1001. [In Russian, English summary].

Golovatch S. I. 1979b. The composition and zoogeographical connections of the Diplopoda of the Middle Asian fauna. Report 2. Zoologicheskiy Zhurnal, 58 (9): 1313-1326. [In Russian, English summary]

GOLOVATCH S. I. 1984. The distribution and faunogenesis of millipedes of the USSR European part. In: CHERNOV Y. I. (ed.), Phylogenesis and Phylocenogenesis, pp. 92-138. Moscow. Nauka Publ. [In Russian]

LOHMANDER H. 1928. Neue Diplopoden aus Ukraine und dem Kaukasus. Trudy Fiziko-Matematichnovo Viddil 6: 525-550.

LOKŠINA I. E. 1969. Opredelitel' dvuparnonogikh mnogonozhek Diplopoda ravninnoï chasti SSSR [Identification book of millipedes (Diplopoda) in the plain part of the USSR European territory]. Nauka Publ., Moskva, 78 pp. [In Russian]

PRISNYT A. V. 2002. A review of the millipede fauna of the south of the Middle-Russian Upland, Russia (Diplopoda). Arthropoda Selecta 10: 297-305.

Stojalowska W., StaręGa W. 1974. Krocionogi Diplopoda. Katalog Fauny Polski 14(1), Instytut Zoologii PAN, PWN, Warszawa, $71 \mathrm{pp}$.

Wytwer J., GoLOVATCH S. I. \& PENEV L. 2009. Variation in millipede (Diplopoda) assemblages in oak woodlands of the Eastern European Plain. Soil Organisms 81 (3): 891-813.

\section{STRESZCZENIE}

\section{[Brachyiulus jawlowskii Lohmander, 1928, nowy dla fauny Polski gatunek krocionoga (Myriapoda: Diplopoda)]}

Brachyiulus jawlowskii (3 samce i 2 samice) został po raz pierwszy stwierdzony w Polsce w dolinie rzeki Bug w Parku Krajobrazowym „Podlaski Przełom Bugu” w pobliżu miejscowości Mogielnica i Mierzwice. Odkryte stanowisko jest najdalej wysuniętym na pólnocny zachód $\mathrm{w}$ obszarze zasięgu gatunku, związanego glównie $\mathrm{z}$ pasem stepów. Powierzchnie badawcze usytuowane byly na lące zalewowej (Poa pratensis-Festuca rubra) tarasu zalewowego wyższego. 